\title{
Operational Model of Cascading Values and Professional Ethics in Organization: A Context for Spiritual Development of Employees
}

\author{
Iraj Soltani $^{1} \&$ Reihaneh Bahraminejad Joneghani ${ }^{2}$ \\ ${ }^{1}$ Science and Research branch, Islamic Azad University, Isfahan, Iran \\ 2 Najafabad Branch, Islamic Azad University, Isfahan, Iran \\ Correspondence: Reihaneh Bahraminejad Joneghani, Industries Engineering (system and Utilization), Najafabad \\ Branch, Islamic Azad University, Isfahan, Iran. Tel: 913-569-7912. E-mail: rahabahrami@ymail.com
}

\author{
Received: May 27, 2012 Accepted: July 10, 2012 Online Published: September 16, 2012 \\ doi:10.5539/ijbm.v7n18p130 URL: http://dx.doi.org/10.5539/ijbm.v7n18p130
}

\begin{abstract}
Compilation of vision, mission and strategies of organization causes systematic and directed movement of organization, but this movement without addressing business values and professional ethics will be spiritless and face serious challenges.

To have successful, dynamic, spirited and sustainable business, it is needed that moral values constitute its basic foundations. Successful business requires at least two major factors: i.e. Competitive strategy and excellent performance in professional ethics. Act upon professional ethics is the major foundation of developed employees and managers in organization. Doing tasks, activities and achieving indicators and goals in moral atmosphere causes relation improvement, confidence making, healthy competition, development of capabilities and happiness in organization. Moral and spirituality are considered as requirements of today business world. So, with regard to importance of professional ethics in business, in this paper the concepts of moral, professional ethics and spirituality have been explained and components and 8 stages of operational model of cascading values and professional ethics in different layers of organization have been presented.
\end{abstract}

Keywords: moral, professional ethics, organizational values, business, human resource development

\section{The Concept of Moral and Professional Ethics}

Leaders and employees of organization should be bound to accepted ethics in order to be success and show it in their tangible behaviors. Moral theory builds a system of codes and regulations that guides human in making decision about good and bad, right and wrong (Mokhtaripoor, M., \& siadat, S. A., 2009).

Moral means principles and standards that defines right and wrong conduct and behavior and shows their distinction. From theory aspect, moral is directed to the point that excellence be toward human strive. The extent of moral will be increased through increasing ability of human in controlling and mastering on nature and managing social structures. So, scope of moral along with increasing ability of human in controlling social and nature environment will be increased and expanded (Soltani, I., 2008). Managers and employees should practiced moral and turn it to behavior. Professional ethics require professionalism in organization. For reinforcing professional culture, development of ethical codes also will be a context for stronger identification and will provide a basis for developing competency model. Ethical codes can both be dominant on members relationship and between customers of organization. Professionalism can be defined as a feature of an individual or a group of employed individuals in a certain job that causes other confidence in desirable doing of their tasks (Alavi, B., \& Moghaddam, K., 2006).

In issues of professional ethics some people emphasize on ethic of jobs owners and neglect organizational ethics and ethical spiritualities. This approach can harm human resource development and causes organizations less pay attention to ethical audits in goal setting, decision making, procedures, relationships with customer, competitors, stock holders, and other interested (Gharamaleki, A., 2006). To have ethical intelligence underpins professional ethics in leaders and managers.

Link and kale consider ethical intelligence as the ability of differentiating right and wrong that is adjustable to world principles. They consider ethical intelligence consisted of four factors including: honesty, responsibility, sympathy, and forgiveness. Managers equipped with ethical intelligence are characterized by following features : 
1) Serving people and organization

2) Justice- oriented in decision and work

3) Honesty in speech and behavior

4) Tend to collective and team work (Mokhtaripoor, M., \& siadat, S. A., 2009).

\section{Spirituality and Professional Ethics in Organization}

Spirituality is an attempt toward creating sensitivity to self, others, superior force (God), searching for what is needed for becoming human and achieving to the position of creating sensitivity to inter and intra personal relationship in work life in order to reach personal development and human excellence. Spirituality has two dimensions: internal (spiritual and psychological) and external (biologic and social) (Abedi Jafari, H., \& Rastgar, A., 2007).

Spirituality at work has three basic elements: i.e. internal, external and combined which divide them onto four different but related results:

1) Leadership and organization: interested in employees, respect other, Actions adjustment, obvious alertness.

2) Employees: masterly skill and knowledge progression, adjustability, and continuous performance.

3) External quality: adjustment, environmental awareness and spirituality feeling toward society.

4) Mutual trust and common responsibilities for common interests.

Internal aspect of spirituality at work is related to essence of your commitment to your value system. Virtually all of the people have a guiding desire to creating difference also they have internal qualities such as honesty, moral, belief, respect, and trust in order to prevent impact of internal factors.

Behavior (spirituality) doesn't shape and their secrets are in their severity. Expectation has impact on severity of these factors. These expectations are the result of our knowledge up to date and in other words are our cognitive processes. So, it is needed cognitive processes to be controlled (Abtahi, H. S., \& KheiAndish, M., 2009).

External aspect of spirituality at work is emphasized more through statements such as "work is a spiritual journey for many of us". Instances such as creativity, variety, calmness and coordination are external manifestations of spirituality at work. Your external world is the mirror image of your internal world. In other words, whatever is out of you is the reflection of what there is within you. Your personality and character greatly determine quality of your relationship with other. Your attitude and reaction of others to you is greatly specified with regard to belief and expectation you have about yourself. The level of your inner needs and willing determines success of your outer world (Tracy, B., 2007).

Combined aspect of work spirituality has two features:

1) Awareness of individuals about existence of spirituality at work is increased.

2) This awareness changes the way of working with others at work. Some combined aspects of spirituality at work include: Perception, honesty, team orientation and acceptance (Sheikhinejad, F., \& Ahmadi, G., 2008).

Cultivation of spirituality at work will have following results:

1) Belief in God

2) To gain calmness and as a result crating a context for thinking about life.

3) Special attention to human and listening to colleagues sayings that improves cooperation.

4) True commitment to improve relationship among human which causes peace and integration in the world.

5) Improvement of human and their surrounding environment (Tracy, B., 2007).

One of the important contexts for establishing spirituality at work is spiritual development of employees and managers. Spiritual development is a process during which psychological welfare of individuals is enhanced and its root can be found in intuitive thinking. Growth and development of spirituality in human cause mental growth and actualizing individual needs. Belonging and self actualization, and moral of employees at/ and out of word will be reinforced. Generally roots of employees spiritual development can be shown in Figure 1. 


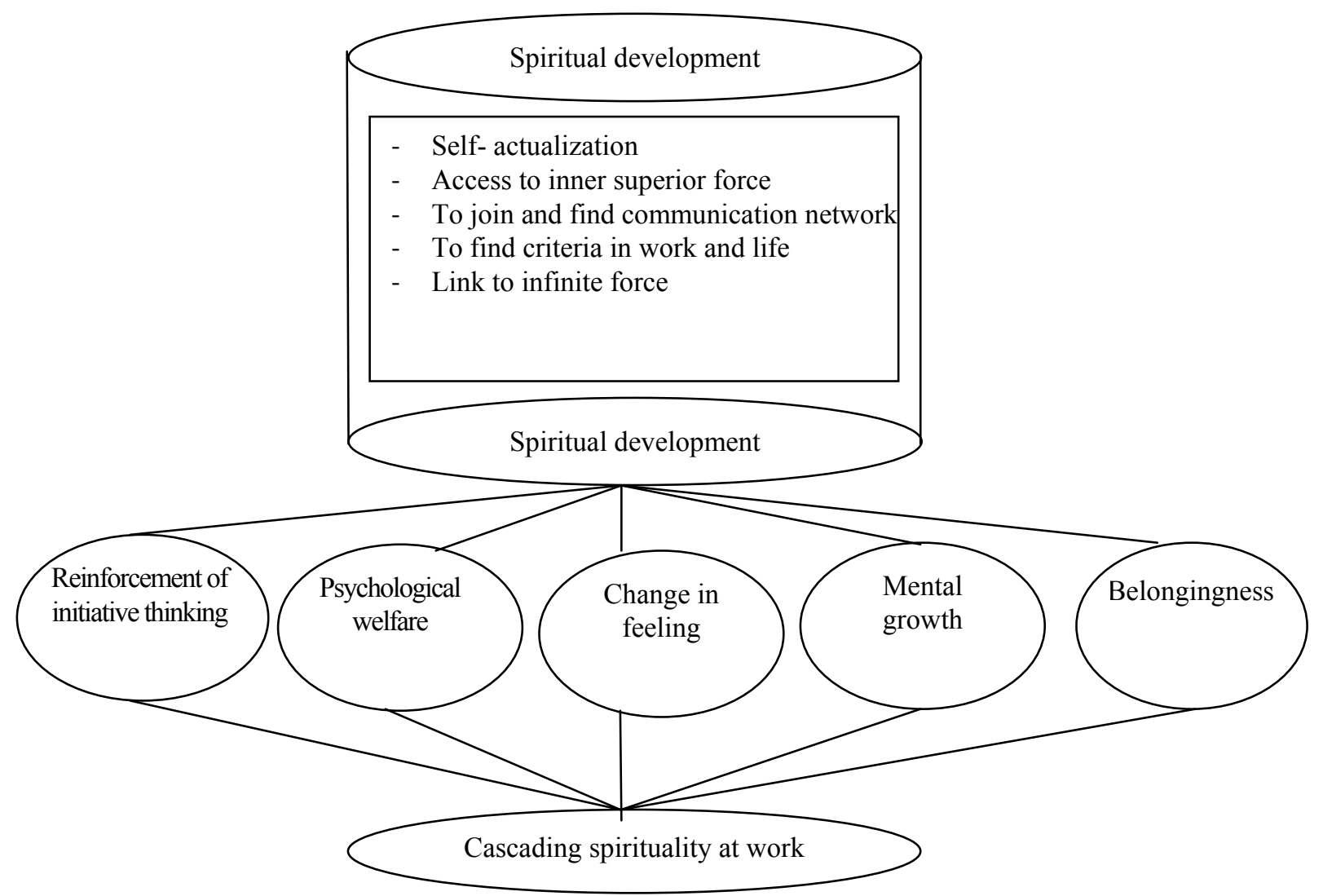

Figure 1. Roots of cascading spirituality at work

With regard to importance of spirituality at work, organizational leaders have a major role in reinforcing and developing spirituality at work. So leaders should play the role of spiritual leader too.

Max De Peri considers spiritual leadership as models of leadership serving, employees involvement and empowerment. Spiritual leaders show belief, enthusiasm and results of their work. John Wesley considers these three factors as major feature and symbol of spiritual leadership (Nargesian, A., 2007). In spiritual leadership model, missions and values shape a company with professional ethics, even beyond this, personal and professional life of employees also shape based on spirituality. Spiritual leaders exile moral identification of their followers and induce deep commitment in them, and join internal and external moral in social relationship of employees, generally, spiritual leadership is consisted of following elements:

- $\quad$ Common spiritual values

- $\quad$ Future vision

- Common purpose

- $\quad$ Empower other

- Influence in other

- Insight

- $\quad$ Serving

- $\quad$ Change in self and other (Sheikhinejad, F., \& Ahmadi, G., 2008).

Domination of spirituality and moral in business atmosphere can be shown in pattern 2 . 


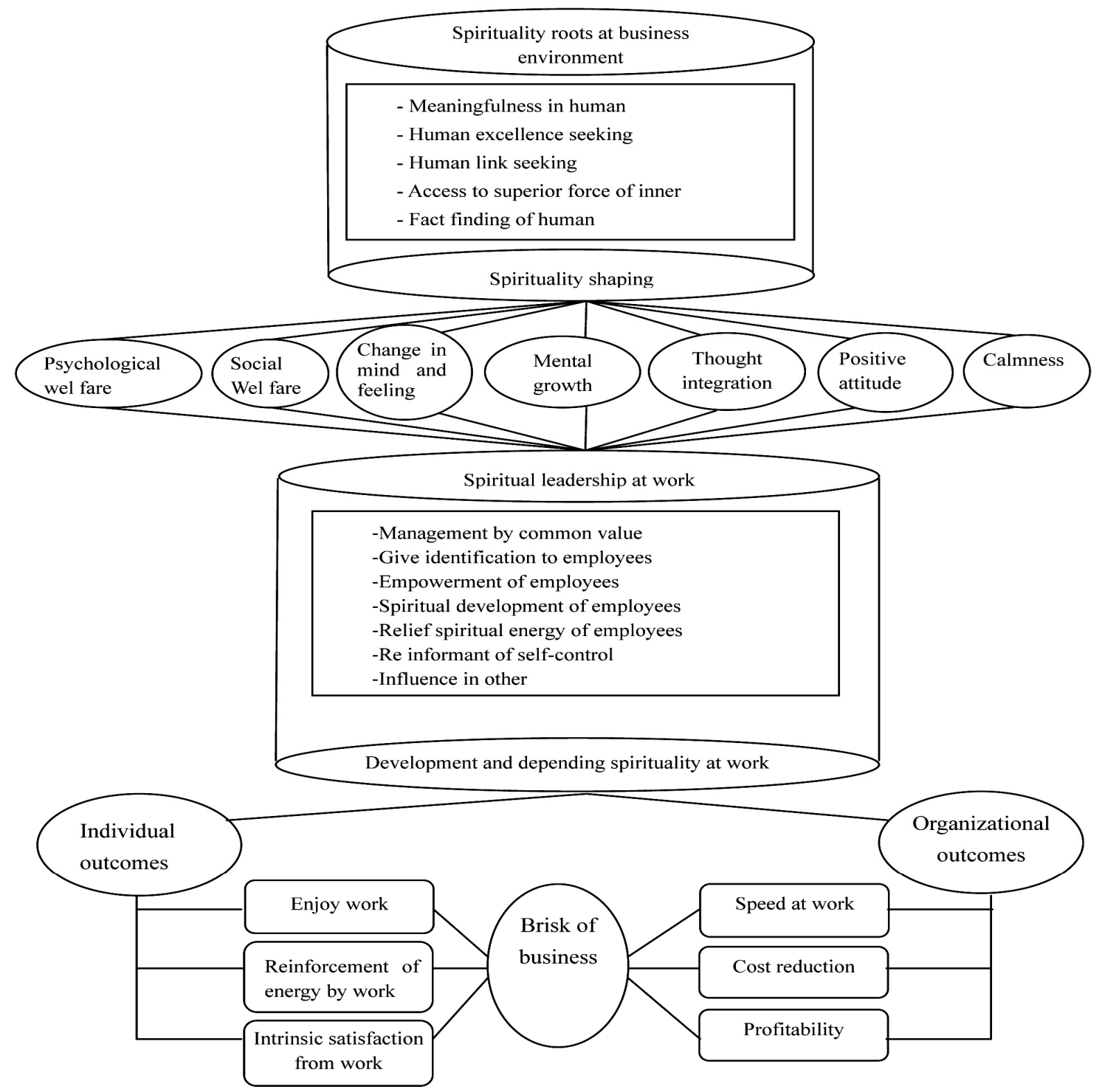

Figure 2. Domination of spirituality and moral in business atmosphere

\section{Stages of Cascading Value and Professional Ethics in Organization}

Organizational value define what are important for organization and business should be followed by considering them. Business value is manifested in professional ethics frame. Compilation of moral charter, values statement and such concepts are valuable but should be flow in different layers of organization in the form of practical behaviors and be integrated in individual work life. One of the challenges face today organization is weakness of following organizational values. The important issue in strategic management process is strategy implementation.

Fortune journal wrote: $70 \%$ of failure of senior managers in U.S.A is not related to their weakness in formulating strategy but it is due to their failure in strategy implementation barriers such as not transferring strategies, lack of employees alignment, lack of management commitment and not allocating resource based on strategies have been mentioned (Kaplan, R. S., \& Norton, D. P., 2006). So, it is needed for success and sustainability, strategies, values and professional ethical be implemented in business and be observed in employees behaviors.

To create fundamental change in behavior based on values requires seeing, feeling and changing. In seeing stage employees become sensitive to values and feeling causes motivating of positive feeling or reduction of negative feeling and increasing emergency sense, hopefulness and belief and changing means new feeling causes change in behavior. Good exploitation of seeing, feeling and changing is a kind of smartness not abnormal neither 
deceptive. And sometimes this process changes behavior of individual and drives them toward seeing, feeling and changing (Katz, J., \& Khan, D., 2006). This process causes growing good habits. Habits are not instinctual, they are reactive and achievable. To change habit based on organizational values taking following steps is recommended:

1) To list behaviors and habits that are not based on values

2) Root finding

3) To find accelerating factors

4) To choose a good behavior for substituting irrelevant habit

5) Rehearsal of relevant habit (Maxwell. J., 2005).

To cascade values and ethical in organization and turning it to operational behaviors it is possible to get help Figure 3.

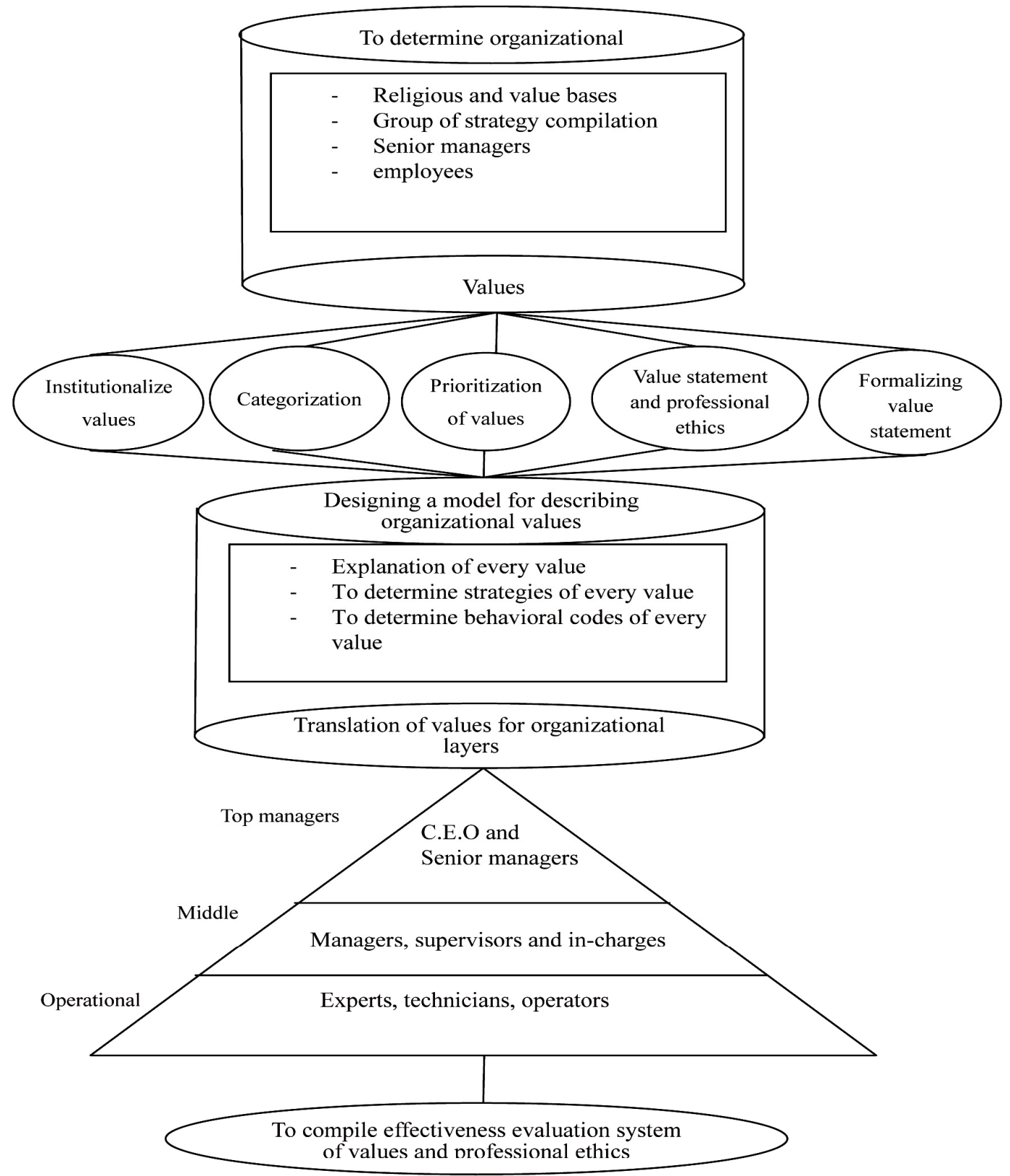

Figure 3. Stages and components of cascading organizational value and professional ethics in business 


\section{Stages and Components of Cascading Values and Professional Ethics in Organization}

\subsection{Determination of Organizational Values and Professional Ethics}

In this stage it is needed to specify required values for supporting business, to do this following steps should be passed through:

1) Survey organizational values and professional ethics bases from the point of employee view in different levels of two following categories.

- $\quad$ Present values

- $\quad$ Required and desirable values

2) Examining compiled ethical and organizational values in organizational strategic planning system.

3) Attention to specified values in council of direct to good tasks and prohibit from bad tasks.

4) Examining values and professional ethics bases emphasized by human resource system.

5) Examining organizational and ethical values of successful internal and external companies.

6) Acid test of values and professional ethics bases with religious and value bases.

Generally, organizational values resulted from mentioned bases can elicit from Figure 4.

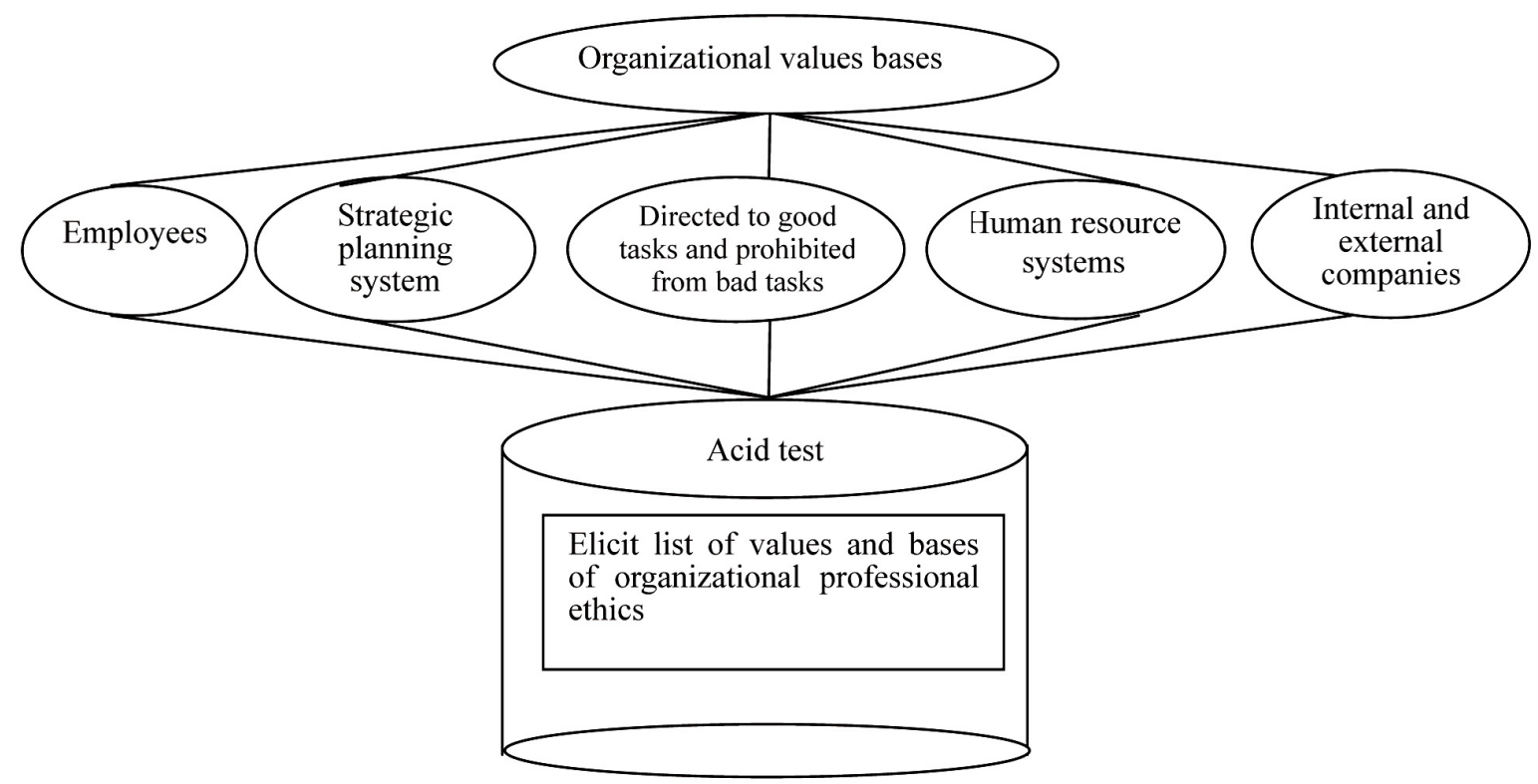

Figure 4. Bases of eliciting organizational values

4.2 Finalizing Values List and Professional Ethics Bases in This Stage List of Values and Moral Bases Derived from Different Resources Should Be Provided, Refined and Finalized

In this regard form Table 1 in which an example of values and mentioned bases specified is presented.

Table 1. Sample list of organizational values

\begin{tabular}{|c|c|c|c|c|c|c|}
\hline \multirow[t]{2}{*}{ Row } & \multirow[t]{2}{*}{ Components of organizational values and professional ethics } & \multicolumn{5}{|c|}{ Reference } \\
\hline & & A & B & $\mathrm{C}$ & $\mathrm{D}$ & $\mathrm{E}$ \\
\hline 1 & Loyalty and organizational involvement & & & & & $\checkmark$ \\
\hline 2 & Honesty & & & & $\checkmark$ & \\
\hline 3 & Work conscience & & & & $\checkmark$ & \\
\hline 4 & Organizational and work discipline & & & & $\checkmark$ & \\
\hline
\end{tabular}




\begin{tabular}{|c|c|c|c|c|c|c|}
\hline 5 & Learning and teaching & & & $\checkmark$ & & \\
\hline 6 & Punctuality & & $\checkmark$ & & & \\
\hline 7 & Respect customer & & $\checkmark$ & & & \\
\hline 8 & Team work & & $\checkmark$ & & & \\
\hline 9 & Participation & & & $\checkmark$ & & \\
\hline 10 & Sacrifice & & & $\checkmark$ & & \\
\hline 11 & Mutual trust & & & & $\checkmark$ & \\
\hline 12 & Customized & & & & $\checkmark$ & \\
\hline 13 & Creativity and innovation & & & & $\checkmark$ & \\
\hline 14 & Profession seeking & & & & $\checkmark$ & \\
\hline 15 & Total attempt & & & $\checkmark$ & & \\
\hline 16 & Enthusiasm & & & $\checkmark$ & & \\
\hline 17 & Confidentiality & $\checkmark$ & & & & \\
\hline 18 & Respect experienced & $\checkmark$ & & & & \\
\hline 19 & Human relations & $\checkmark$ & & & & \\
\hline 20 & Accountability & & & & & $\checkmark$ \\
\hline 21 & Prefer organizational interests over individual interest & & & & & $\checkmark$ \\
\hline
\end{tabular}

\subsection{Categorization of Values and Professional Ethics Bases}

After finalizing these values, they should be categorized, to categorize them it is possible to act as followings:

- To determine business values

- To determine moral values

- To determine combined values (business and moral)

- To determine job values

- To determine values related to customers

- To determine values related to employees

- To determine values related to management

- $\quad$ To determine social values

\subsection{Prioritization of Values and Professional Ethics}

To plan better for cascading values and to focus on pivotal values, values and professional ethics bases should be prioritized.

Following stages should be passed through for prioritizing:

1) To determine evaluation standards which in this regard following instances can be referred:

- Help of value in business brisk

- Help of value in spiritual development of employees

- Strategic importance of organizational value

- Simply turning value to behavioral codes

- Coordination of value with company strategies

2) Provide scoring system for evaluating values

3) Provide matrix of evaluating values according to Table 2.

4) Evaluation by managers and employees

5) Value prioritization 
Table 2. Matrix of evaluating organizational values for prioritizing

\begin{tabular}{|c|c|c|c|c|c|c|c|c|c|c|c|c|c|c|c|c|c|c|c|c|c|c|c|}
\hline \multirow{3}{*}{ Row } & \multirow{3}{*}{$\begin{array}{c}\text { Title of } \\
\text { value or } \\
\text { professional } \\
\text { ethics }\end{array}$} & \multicolumn{22}{|c|}{ Standards of value evaluation } \\
\hline & & \multicolumn{5}{|c|}{ Standard 1} & \multicolumn{4}{|c|}{ Standard 2} & \multicolumn{4}{|c|}{ Standard 3} & \multicolumn{4}{|c|}{ Standard 4} & \multicolumn{5}{|c|}{ Standard 5} \\
\hline & & 1 & 2 & 3 & 4 & 5 & 1 & 23 & 34 & 5 & 1 & 23 & 34 & 5 & 1 & 2 & 34 & $4 \quad 5$ & 51 & 2 & 3 & 4 & 5 \\
\hline 1 & A & & & & & & & & & & & & & & & & & & & & & & \\
\hline 2 & B & & & & & & & & & & & & & & & & & & & & & & \\
\hline 3 & $\mathrm{C}$ & & & & & & & & & & & & & & & & & & & & & & \\
\hline 4 & $\mathrm{D}$ & & & & & & & & & & & & & & & & & & & & & & \\
\hline 5 & $\mathrm{E}$ & & & & & & & & & & & & & & & & & & & & & & \\
\hline
\end{tabular}

\subsection{Provide Value Statement and Moral Charter of Organization}

After evaluating and prioritizing organizational values, the most important value and those which have the highest points should be selected as pivotal value and value statement of organization is compiled and through cascading it in organizational strategic planning system, be addressed.

\subsection{Description of Organizational Values and Professional Ethics Bases}

In this stage, values and moral bases in terms of dimension's quality, content should be described and explained. To offer values and moral bases in the frame of words and general statement cause ambiguity and tangle and common subjectivity faces difficulties. Description and explanation of organization values increase common subjectivity. To create common language understanding related to values, titles of values should be recorded and described according to form Table 3 and then points and pivotal key of every value should be elicited.

Table 3. Explanation of values and professional ethics bases in organization

\begin{tabular}{cccc}
\hline Row. & $\begin{array}{c}\text { Titles of organizational values and } \\
\text { professional ethics bases }\end{array}$ & $\begin{array}{c}\text { Description and } \\
\text { explanation of value }\end{array}$ & Elicit key points \\
\hline 1 & A & & \\
2 & B & & \\
3 & C & \\
\hline
\end{tabular}

\subsection{Translation and Cascading Organizational Values and Professional Ethics Bases}

Translation and flowing values and ethics are among the most important stages related to organizational values, because legalization of values is depended on flowing them and act. Upon them in organization. To translate and flow values, following stages should be passed through:

1) To turn values to behaviors following steps should be taken:

- Definition of each value

- To determine strategies of every value

- To determine expected behaviors of every value

- To determine required practices for practicing values

To do aforesaid practices, it is possible to use Table 4.

Table 4. The way of turning values to expected behavior

\begin{tabular}{cllll}
\hline Row. & $\begin{array}{c}\text { Components } \\
\text { of values }\end{array}$ & \multicolumn{1}{c}{ Related strategies } & \multicolumn{1}{c}{$\begin{array}{c}\text { Expected behaviors (behavioral } \\
\text { codes) }\end{array}$} & $\begin{array}{c}\text { Action plan for } \\
\text { practicing values }\end{array}$ \\
\hline 1 & (sample) & (sample) & (sample) & -Group procedures \\
& Team work & $\begin{array}{l}\text { - Encouragement team work } \\
\text { - Structure making for team }\end{array}$ & $\begin{array}{l}\text { - On time participation in sessions } \\
\text { - Define improvement projects }\end{array}$ & $\begin{array}{l}\text { - Link teamwork to } \\
\text { compensation system } \\
\end{array}$ \\
& work & $\begin{array}{l}\text { Problem solving through } \\
\text { instruction }\end{array}$ & \\
2 & & & \\
3 & & & & \\
\hline
\end{tabular}




\section{2) Translation of values}

Values should be translated in an understandable language for different layers, in this section following actions help in better and depth cascading.

- To specify target groups for cascading organization values

- To determine values behaviors indicators relevant to each organizational layer

- To determine tools, means and transfer of cascading values in different layers.

Aforesaid stages can be implemented according to Table 5 and 6 :

Table 5. The way and translation of organizational values

\begin{tabular}{|c|c|c|c|}
\hline Row. & $\begin{array}{c}\text { Target groups for cascading } \\
\text { values }\end{array}$ & $\begin{array}{l}\text { To determine behavioral } \\
\text { indicators }\end{array}$ & $\begin{array}{l}\text { To determine tools and means for } \\
\text { transferring values }\end{array}$ \\
\hline 1 & Deputies & Pivotal values & Sessions, seminars, SMS, brochure \\
\hline 2 & Senior and middle managers & Pivotal values and key axial & Sessions, seminars, goal boards \\
\hline 3 & Heads and general foremen & Values pivotal key and plans & $\begin{array}{l}\text { Goal board, training seminar, goal } \\
\text { booklets management automation }\end{array}$ \\
\hline 4 & Shift supervisors & $\begin{array}{l}\text { Plans related to values and } \\
\text { activities }\end{array}$ & $\begin{array}{l}\text { Newsletter }- \text { total booklets of } \\
\text { organization values }\end{array}$ \\
\hline & & & Training seminars \\
\hline 5 & Expects and technicians & $\begin{array}{l}\text { Activities and behaviors } \\
\text { indicators of values }\end{array}$ & $\begin{array}{l}\text { Website, training seminars, } \\
\text { management automation }\end{array}$ \\
\hline 6 & $\begin{array}{l}\text { Operators of production repair } \\
\text { and staff }\end{array}$ & $\begin{array}{l}\text { Defined and simple } \\
\text { behavioral indicators }\end{array}$ & $\begin{array}{l}\text { Special printed cards sessions } \\
\text { - Printing values in newsletter } \\
\text { - Information boards }\end{array}$ \\
\hline
\end{tabular}

Table 6. Sample of value translations to operational behaviors in operator layer of organization

\begin{tabular}{|c|c|c|}
\hline Values & Target group & Behaviors \\
\hline $\begin{array}{l}\text { Development of participation and } \\
\text { organizational communication }\end{array}$ & Operators & $\begin{array}{l}\text { - Provide more suggestions } \\
\text { - Define more QC,S } \\
\text { - Cooperation between production and repaire }\end{array}$ \\
\hline $\begin{array}{l}\text { Excellence and continuous } \\
\text { improvement }\end{array}$ & Operators & $\begin{array}{l}\text { - Review work methods } \\
\text { - Omission of unnecessary work } \\
\text { - Provide suggestion for improving work }\end{array}$ \\
\hline Safe work & Operators & $\begin{array}{l}\text { - Follow safety procedures of equipments } \\
\text { - Attend safety training courses } \\
\text { - To fill forms related to near miss } \\
\text { - Complete using of individual } \\
\text { - Considering safety of equipment during repair } \\
\text { and fixation }\end{array}$ \\
\hline Respect customers and colleges & Operators & $\begin{array}{l}\text { - Respect each other } \\
\text { - To prevent using irrelevant speech in } \\
\text { workshop } \\
\text { - Report full condition to next shift } \\
\text { - Respect employees of coratractors } \\
\text { - Cooperation during repair and fixation }\end{array}$ \\
\hline
\end{tabular}




\subsection{To Determine Effectiveness of Cascading Organizational Values}

After cascading values and bases of ethics, it is needed that the extent of transferring values and its impact on employees and business atmosphere be determined. To assess the extent of values effectiveness and professional ethics following actions is suggested:

- $\quad$ To specify target groups

- To determine methods of getting feedback: in this regard it is possible to use questionnaire, interview, selection of target groups and observation.

- $\quad$ To determine measures related to measuring effectiveness of values

In this regard it is possible to use Table 7.

Table 7. Measures related to determining effectiveness of organizational values

\begin{tabular}{|c|c|c|c|c|c|c|c|c|c|c|c|}
\hline \multirow{2}{*}{ Row. } & \multirow{2}{*}{ Components and measures } & \multicolumn{10}{|c|}{$\rightarrow$ very high } \\
\hline & & 1 & 2 & 3 & 4 & 5 & 6 & 7 & 8 & 9 & 10 \\
\hline 1 & Improvement of business atmosphere & & & & & & & & & & \\
\hline 2 & $\begin{array}{l}\text { Improvement relationship at level of organization and } \\
\text { employees }\end{array}$ & & & & & & & & & & \\
\hline 3 & Reinforcement of self - control & & & & & & & & & & \\
\hline 4 & Reinforcement of organizational trust & & & & & & & & & & \\
\hline 5 & Reinforcement of energy due to domination of values & & & & & & & & & & \\
\hline 6 & Reinforcement of internal satisfaction of work & & & & & & & & & & \\
\hline 7 & Improvement of psychological climate of work & & & & & & & & & & \\
\hline 8 & Improvement of organizational integration & & & & & & & & & & \\
\hline 9 & Reinforcement of positive attitude & & & & & & & & & & \\
\hline 10 & State of internal calmness & & & & & & & & & & \\
\hline 11 & State of calmness of work & & & & & & & & & & \\
\hline 12 & Forgiveness & & & & & & & & & & \\
\hline 13 & Tolerance each other & & & & & & & & & & \\
\hline 14 & Increasing saving behaviors & & & & & & & & & & \\
\hline 15 & Development of spirituality in employees & & & & & & & & & & \\
\hline
\end{tabular}

\section{Research Limitation}

1) Shortage of references concerning ethical codes in operational organizations.

2) Shortage of operational ethical indicators for different levels of organizations.

3) Weakness in common understanding for spiritual development of employees.

4) Different ties in accessing to employees ethical subjectivity in organization and uniqueness of ethics for individual in organizations.

\section{Conclusion}

Brisk of business climate requires dynamic and smart plans and activities. Profit ability in business is an important principle for interested in organization, but survival and profitability require moral management of business. Domination of ethical and organizational values cause reinforcing mutual respect, self-control, meaning fullness, organizational and individual identification, belonging, conscience, honesty in speech and conduct in organization and individuals enjoy work and organization. To make organizational values base of all employees work, it is needed that values and ethics be specified and turned to behavioral codes and be flown indifferent layers and its impact be assessed. In this paper an operational model for cascading organizational values was presented. 


\section{References}

Abedi Jafari, H., \& Rastgar, A. (2007). Appearance of spirituality in organization. Jranian management science.

Abtahi, H. S., \& KheiAndish, M. (2009). Self - control model in organization with Islamic attitude. Tadbir journal No.213.

Alavi, B., \& Moghaddam, K. (2006). The role of competency standard development in becoming more professional in HRM. 3rd conference of HRD, Tehran.

Gharamaleki, A. (2006). Ethical predicable of organization and human resource development. 3rd conference of H.R.D.

Kaplan, R. S., \& Norton, D. P. (2006). Strategy-oriented organization. Translated by Bakhatiary P. Publication of industrial management organization.

Katz, J., \& Khan, D. (2006). Eight steps of change translated by mahjoob. M.A. Fara cultural organization.

Maxwell. J. (2005). Attitude management. Translated by Amini, F. Fara cultural organization.

Mokhtaripoor, M., \& siadat, S. A. (2009). Management by ethical intelligence. Tadbir journal No. 205.

Nargesian, A. (2007). Spiritual leadership in current organization. Tadbir journal No.189.

Sheikhinejad, F., \& Ahmadi, G. (2008). Management in the light of spirituality. Tabdir journal No 202.

Soltani, I. (2008). Self-assessment tools and improvement in HRM (P. 35). Esfahan: Arkan Publication.

Tracy, B. (2007). Greate your future. Translated by gharachedaghi, M, Tehran Asimpublication. 